Postprint of: Almiron, Núria; Boykoff, Maxwell; Narberhaus, Marta \& Heras, Paco. 2020. Dominant counter-frames in influential climate contrarian European think tanks. Climatic Change. 162(4), $2003-$ 2020. https://doi.org/10.1007/s10584-020-02820-4

Online access here.

\title{
Dominant counter-frames in influential climate contrarian European think tanks
}

\author{
Núria Almiron, Maxwell Boykoff, Marta Narberhaus \& Francisco Heras
}

Abstract: Numerous studies to date have interrogated United States (US) think tanks-and their networks-involved in climate change countermovement (CCM). Comparatively in Europe (EU), research has been lacking. This investigation therefore attends to that gap. We conducted a frame analysis on eight most prominent contrarian think tanks in six countries and four languages in Europe over 24 years (1994-2018). We found that there has been consistent contrarian framing through think tanks in the EU regarding climate change. Yet, we found a proliferation of contrarian outputs particularly in recent years. This uptick in quantity correlates with increases in CCM activities in the US. Our content analyses showed that well-worn climate change counter-frames spread by US CCM organizations were consistently circulated by European organizations as well. Moreover, we found that, as in the US, neoliberal ideological stances stood out as the most frequently taken up by contrarian think tanks in Europe. As such, we documented that CCM tropes and activities have flowed strongly between US and EU countries.

\section{Introduction}

The role of think tank networks involved in climate change contrarianism in the United States (US) has been examined by a varied number of scholars and organizations, and because of its relevance and magnitude, described as a much influential lobby that labeled the climate contrarian movement (CCM) organizations (e.g., Boykoff 2016; Farrell 2016; Brulle 2020).

Analyses of the US constellation of contrarian think tanks provided by the research to date demonstrate that we face a complex phenomenon in which economic sponsorship is not the only factor in their capacity for influence. Cultural politics have contributed as well to this state of affairs. Cultural politics are dynamic and contested spaces where various actors battle to shape public understanding and engagement. They are arenas where formal climate science, policy, and politics operating at multiple scales permeate the spaces of the everyday (Boykoff 2011). Cultural politics refer to dynamic and contested processes whereby meaning is con- structed and negotiated (Norgaard 2011), and involves not only the portrayals that gain traction in discourses but also those that are absent from them or silenced (Derrida 1978).

Together, political contexts supporting free-market policies over recent decades have proven to be fertile ground for the seeds of the contrarian discourse; complicit mass media as disseminators have also played significant roles (Boykoff 2011). At the center of these complexities, it is important to note the power and influence of CCM think tanks by way of their capacity and funding. These CCMs then shape policy processes and public opinion (Medvetz 2012).

The combination of carbon-based industry concentrations of power and cultural and political opposition to environmental movements in the US may explain why contrarianism has spread faster in the US than in Europe, where the climate contrarian discourse has not been as explicit and visible as in America. Accordingly, these trends paired with pre-capitalism histories in Europe (Boykoff and Rajan 2007; Hornsey et al. 2018) help explain how climate contrarianism has been comparatively under research in Europe.

The investigation presented in this paper attends to that gap by studying CCM counter-framing amongst European think tanks. To this end, we identified the most relevant think tanks in Europe and conducted 
a frame analysis on eight most prominent contrarian think tanks over a 24-year period (1994-2018), including six countries and four languages.

This paper is organized as follows: First we provide a short overview of climate change contrarian countermovement (CCM) activities. The literature applies mostly to the US and reflects the interdisciplinarity of the core research that this paper is contributing to, by adding the European analysis. Second, a method section provides a summary of the procedure followed for the study both regarding the selection of the eight organizations and the framing analysis. Then the results are provided followed by a discussion including the policy, sociological, and discourse-related aspects and the conclusions.

\section{The climate change contrarian movement}

In this research-through our analyses of eight CCM organizations in six EU countries-we sought to better understand how political economic and cultural factors influence across US and EU contexts may have contributed to differing CCM discourses.

Since the late 1990s, research conducted on the constellation of contrarian think tanks has provided a wealth of data in the US regarding CCM influence on US policies, media, and the public opinion regarding anthropogenic climate change. CCM organizations have been de- fined as groups that advocate against policies that seek action to mitigate climate change, especially mandatory restrictions and penalties on greenhouse gas emissions (Brulle 2014). These movements also advocate against substantive action to adapt to or mitigate climate change (McCright and Dunlap 2000).

Researchers have consistently unveiled and mapped discursive alignments and material links between US think tanks and corporate economic interests (Brulle 2014; McCright and Dunlap 2000; McCright and Dunlap 2003; Rowell 2007; Union of Concerned Scientists 2007; Farrell 2016). This architecture has been referred to as a denial machine (Dunlap 2013). In particular, research has traced how CCM organizations are strongly linked with right-wing think tanks (Dunlap and Jacques 2013; Jacques et al. 2008). Conservative think tanks, along with a few trade associations and other advocacy organizations, have been described as "key organizational components of a well-organized climate change countermovement that has not only played a major role in confounding public understanding of climate science, but also success- fully delayed meaningful government policy actions to address the issue" (Brulle 2014: 681). Research has also pointed out that while economic sponsorship is crucial, it is not the only factor to explain the major influence of this countermovement-additional factors are favorable political contexts-e.g., a prevailing dominance of neoliberal ideas-as well as ideological affinities. Over recent decades, these ingredients have contributed to fertile grounds for seeds of the contrarian discourse to grow and flourish (Plehwe 2014).

Developments over these past decades have come amid a backdrop of long histories of cultural opposition to environmental movements in the US (Boykoff 2016). The objective nature of scientific research traditionally allocating legitimacy and prestige to academia has been imported by contrarian think tanks with the cooperation of policy experts with academic profiles (Medvetz 2012). Previous research has also documented complicity of mass media as disseminators (Boykoff 2011). Politics, academia, and the media have effectively colluded (knowingly or unknowingly) with the economic elite interests, creating often indirect and subtle yet strong underlying dependencies between each other (Plehwe 2011). Importantly, Farrell uncovered how the organizational power within US-based contrarian networks and the magnitude of semantic similarity are both predicted by ties to elite corporate benefactors (2016).

In section 3.2 of this paper, we summarize (Box 1 ) the main arguments circulated by the US think tanks advocating against the scientific agreement on the anthropogenic causes of climate change and its severe consequences (Cook et al. 2018) for its comparison with the European research conducted for this paper. 
By contrast, research into these CCM activities in Europe has been much more limited regarding the role of think tanks. This has been due in part to the fact that the number and scope of contrarian organizations and experts have been considered marginal in the region. There are, however, some interesting results for the European case. Beder (2001) was amongst the first authors to unveil the connection between neoliberal think tanks and the promotion of free market environmentalism in English-speaking countries, including the UK. Since this ideology advocates for giving priority to the economy to solve the environmental problems, and since this priority is what has caused environmental problems in the first place, this link illuminates the core roots of climate change inaction at the policy level. Plehwe (2014), in his turn, has highlighted the links between the European and US organizations. For instance, he recalls that amongst the denialist Nongovernmental International Panel on Climate Change (NIPCC), there were a number of European authors, and that close links between European think tank networks and US and Australian think tanks can be identified (like the Committee for a Constructive Tomorrow, CFACT, set up in the US in 1985 and extended to Europe in 2004 and the

Australian Joan Nenova's climate change "skeptic handbook" translated to German by the Australian Hayek Institute). Plehwe (2017) has also studied the social networks of influence in Europe and reported on the relevant role of neoliberal circles in the market of ideas regarding European integration. Though the paper does not focus on climate change, it connects neoliberal forces to climate change inaction because environmental protection has been one of the fields more integrated, and neoliberals in Europe oppose integration. This approach, connecting neoliberalism and right-wing ideologies with climate change denialism, is the current dominant line of research in Europe regarding climate change contrarianism and will be further expanded in the discussion of this paper.

\section{Methods}

The scope, resources, and prominence of CCM think tanks in Europe is arguably more complicated to measure for researchers in Europe than it is in the US. The complexity of the multinational, multilingual Europe, alongside the existence of distinct political contexts and cultural backgrounds, have increased the challenges of tracking trends of climate change denial and contrarian narratives in this region. Yet, this study has confronted these complexities and challenges as we constructed a methodological approach to examine these dynamics.

Following a multiple-stage procedure, we first mapped the climate think tanks counter- movement in Europe. Second, we systematically examined their output to identify a climate contrarian discourse: that is the dissemination of messages advocating against the evidences of human-induced global warming or casting doubt on climate change as a problem to varied degrees. The latter was conducted by means of a frame analysis.

The study focuses on think tanks alone, in spite of that there may be other sources of climate contrarian discourse in Europe. This is so because this study attempts to expand the literature on the climate contrarian movement, so far devoted in the US region to think tanks, and because this type of organizations are the ones defined as potentially more influential by the literature, compared to blogs or nonadvocacy research organizations.

\subsection{Mapping contrarian think tanks in Europe}

To build the sample of think tanks spreading contrarian views on anthropogenic climate change, we used five main sources: (1) academic research and media representations; (2) US climate denial conferences; (3) think tank databases (Think Tank Network Research, Think Tank Directory); (4) rightwing libertarian think tank networks (Atlas Network, former Stockholm Network); and (5) expert consultations.

Because of the language abilities of the research team, the selection of the sample consisted of think tanks publishing online in English, German, French, and Spanish. By analyzing discourses in think tanks in the most prevalent languages on Europe, we were able to thus include in our sample relevant and influential organizations in the region. 
From the abovementioned five sources, we collected at a first stage 12 think tanks that included multiple- and single-issue organizations (focusing only on environment or on many other topics) for which we could identify at least one text in their websites showing a clear skeptic/denial/contrarian stance towards anthropogenic climate change.

After checking the availability and reliability of archives as well as the volume of their output, the sample was narrowed to eight organizations (by discarding think tanks who did not provide a search engine or produced less than seven texts). These eight organizations include the most relevant disseminators of contrarian climate change messages with output in English, German, French, and Spanish and are located in six different European countries:

- Austria: Austrian Economics Centre (AEC)

- France: Institut Économique Molinari (IEM)

- Germany: Europäisches Institut für Klima und Energie (EIKE)

- Spain: Instituto Juan de Mariana (IJM)

- Switzerland: Liberales Institut (LI)

- United Kingdom: Centre for Policy Studies (CPS), Institute of Economic Affairs (IEA), The Global Warming Policy Foundation (GWPF)

The studied organizations included old and newly established centers. The senior think tank of our sample is the well-known Institute of Economic Affairs (IEA), created in the United Kingdom (UK) in 1955. Based in Westminster, London, this think tank describes itself as "the UK's original free-market think-tank" and is considered as one of the most influential, corporate-funded, conservative think tanks in the UK, also playing a central role in promoting free market environmentalism in this country (Beder 2001). It has been disclosed that oil giant BP has been one of IEA funders and that the organization raises money from gambling companies and US donors that support its push for a hard Brexit and a deregulatory US-UK trade deal, while facilitating behind closed doors access to cabinet ministers to its donors (CEO 2010; Carter and Ross 2018). IEA has been strongly lobbying for a hard Brexit (Monbiot 2018) along with the other two British think tanks of our sample, the Centre for Policy Studies (CPS) and The Global Warming Policy Foundation (GWPF). These three organizations are members of the so-called Tufton Street network, the London street where many of the UK's leading pro-Brexit campaign groups and think tanks have offices (Farand et al. 2019).

The Centre for Policy Studies (CPS), created in London in 1974, describes itself as "Britain's leading centre-right think tank" with the mission of developing "a new generation of conservative thinking, built around promoting enterprise, ownership and prosperity". CPS is considered one of the two most influential think tanks in the UK, alongside the IEA. Both have historical links with the British conservative party (Beder 2001).

The third British organization of the sample, The Global Warming Policy Foundation (GWPF), is a think tank that established in 2009. GWPF is fully devoted to the issue of climate change. They are also considered the UK leading voice in the media for the climate change denial (CEO 2010). GWPF was set by the former Tory chancellor Nigel Lawson and is said to be created mirroring US denial organizationsUS corporations being actually an important funding source (Mandel 2016).

Outside the UK, the next oldest organization included in our analyses is Liberales Institut (LI), established in Zurich, Switzerland in 1979. A declared follower of the Austrian School of Economics, the LI describes itself devoted to "the research and dissemination of the ideas of liberty" (Liberales Institut 2020). Details about this think tank's funding or corporate links are undisclosed.

Next in the sample, according to its date of creation, is French Institute Économique Molinari (IEM), founded in 2003. In spite of their statement of holding offices in Paris, Brussels, and Montreal, this is a very small center named after the Belgian economist Gustave de Molinari (1819-1912). Molinari is credited as an early proponent of the anarcho-capitalist ideas in Europe that inspired US libertarians (Raico 2011). IEM promotes a "tax freedom day" in France, following the father of economic 
neoliberalism Milton Friedman, who relaunched the idea in the 1980s in the US (Pariente and Laurent 2014).

The Spanish think tank in the sample, Instituto Juan de Mariana (IJM), was created in 2005 in Madrid. With close links to hard core US climate change deniers, including funding from the US oil industry (CEO 2010), IJM is named after the Spanish philosopher Juan de Mariana, who defended private property and encouraged limits on government (Rothbard 2010). When the IJM was launched, it began with a seminar against the Kyoto Protocol that was attended by climate change skeptic Christopher Horner from the Competitive Enterprise Institute. The center has also cosponsored several International Conferences on Climate Change organized by the Heartland Institute-the Chicago-based free market think tank at the forefront of denying the scientific evidence for man-made climate change in the US. IJM is also close to several radical free-market European think tanks.

The two remaining think tanks of our sample are both established in 2007. Austrian Economics Centre $(A E C)$ is settled in Vienna, Austria, and Europäisches Institut für Klima und Energie (EIKE) is headquartered in Hannover, Germany. AEC publicly states that its main goal is to disseminate the ideas of the Austrian School of Economics. Accordingly, it also promotes events like the "tax freedom day." As the majority of the other organizations of the sample, the AEC has close links with the US right-wing countermovement, including The Heritage Foundation, Cato Institute, Competitive Enterprise Institute, or Americans for Tax Reform, amongst others as stated in its website. It also created the Friends of the Austrian Economics Center in the US to facilitate contributions from US donors. It is worthy to remember that some of the US organizations mentioned by AEC as "partners," like Americans for Tax Reform, are considered to act as funding vehicles of the oil industry (Mayer 2017).

Finally, German Europäisches Institut für Klima und Energie (EIKE) is the second think tank fully devoted to climate change issues of our sample-besides the GWPF. It has been reported that EIKE works closely with the right populist Alternative for Germany (AfD) party and is very well-connected with the US climate counter-movement-including having hosted some Heartland Institute conferences in the past and being in charge of the European subsidiary of CFACT, a US lobby organization who has received large sums of money form ExxonMobil (Deleja-Hotko et al. 2019).

In sum, the organizations selected for our analysis were chosen because they visibly produced climate change denial output-the extent and content of which was precisely the goal of our research. Moreover, the organizations in our map share further singular traits. First, the majority of them maintain relevant links with the US denial countermovement-including US funding related to it. Second, they all seem to hold a similar ideological bias-close to neoliberal and right-wing stances. In fact, all the organizations gathered for our analysis, except EIKE and GWPF, are members of the

Atlas Network, the US-based network of pro free-market, libertarian think tanks from all over the world. Third, in the case of the UK think tanks, the three of them count amongst the strongest lobbies for a hard Brexit.

Finally, this set of think tanks are also considered relevant organizations in Europe. With the exception of EIKE and LI, the other six organizations of our sample are all mentioned amongst the most influential think tanks in the 2018 Global Go To Think Tank Index Report (McGann 2019). The reason why LI and EIKE are not included in the McGann report, in spite of being an old and consolidate think tank the former and the organization with the larger contrarian output the latter, may be due to the characteristics of this report. ${ }^{1}$

In order to examine CCM discourses emanating from these organizations, we systematically collected all available documents in the think tanks' websites with mentions to climate change and global warming in

1 Global Go to Think Tank Index is an index build upon the nominations and rankings made by a panel of experts on the basis of a large list of qualitative criteria that the experts assess according to their perception. For the 2018 Global Go to Think Tank Index, the panel included over 1796 peer institutions and experts from the print and electronic media, academia, public and private donor institutions, and governments around the world (McGann 2019). 
English (or "Klimawandel" and "Erderwärmung," "changement climatique" and "réchuffement," and "cambio climático" and "calentamiento global" in German, French or Spanish, respectively) at the end of 2018. After discarding texts with a non-substantive passing mention of climate change or global warming, we ended up with 1669 (N) texts published within a time range going from 1994 to 2018.

From the sample, one particular think tank emerged prominently, German EIKE, with $73.46 \%$ of all texts gathered, and one particular country stand out with three organizations located in it, the United Kingdom. Details for the sample are shown in Table 1.

We do not have an explanation for the German bias of the sample, with EIKE including almost three quarters of all the texts gathered. The research engines in their websites provided a similar time range of posts for all the organizations (around 10 years) with only two exceptions including a larger time range (IEA and JDM), but of course, the think tanks may have not made available all their output through their websites. In order to address this imbalance, the data provided in the results of this study always takes the German bias into account for the general results and offers data disaggregated by think tanks.

\subsection{Framing climate contrarian discourse}

After the selection of the sample and the collection of all the documents meeting our criteria, we conducted a frame analysis based on the tradition first put forth by Goffman (1974), which suggested that how something is presented to the audience (the frame) influences the choices people make about how to process that information. In essence, "framing is the process by which a communication source defines and constructs a political issue or public controversy" (Nelson et al. 1997: 567). We examined a priori codes along with an openness to other codes that may have emerged. This is an approach increasingly deployed and accepted in qualitative analysis (Clifford and Travis 2018; Bazeley and Jackson 2013; Stemler 2001).

As for the frames tested, we built a list following the main counterarguments found in the US countermovement as identified by Cook et al. (2018)-we call them counter-frames as McCright et al. (2015), since they counter the consensus around anthropogenic climate change-by consensus, we refer to the scientific agreement that earth's climate is heating up and that human activities are a significant cause (Cook et al. 2016). In addition to traditional scientific counter-frames, we added other relevant non-scientific frames to further interrogate think tanks' discursive influences. As can be seen in Box 1 , we divided the counter-frames into three main blocks: counter-frames related to general scientific claims, counter-frames related to specific scientific claims, and counter-frames related to non-scientific claims. Finally, the main focus of the texts (policies/solutions, scientific approach, economic approach, ethical approach, other) was also coded.

\section{Box 1. An overview of the counter-frames analyzed}

\section{A. General scientific claims:}

A1. Contesting IPCC legitimacy (implicitly or explicitly)

A2. Contesting scientific consensus \& legitimacy (not IPCC)

A3. Contesting scientific dissemination (by politicians, media, and other).

Examples: directly criticizing or casting doubts on IPCC reports and working groups, on other scientists or on disseminators because they are alarmist, models used are imperfect, models' predictions have failed, they misrepresent data, they are based on poor data, they use unreliable sources).

B. Specific scientific claims:

B4. It is not happening (climate change or global warming)

B5. It is happening, but we do not know how serious it is or it is not seriousB6. It is happening, but it is good/not bad (either global warming or particular issues of it)

B7. It is happening, but it is not us or it is not only us (other issues are also causes/main causes).

B8. It is happening, but we have other major problems

B9. It is happening, but any policy will be worse than warming. 
Examples: It is not warming, Antarctic sea ice is increasing, it can be cyclical, temperature rise is marginal, $\mathrm{CO} 2$ is not bad, the Sun is the main cause, poverty and hunger are other equally major problems.

\section{Non-scientific claims:}

C10. Criticism of non-scientist defenders \& messages \& policies on a non-scientific basis.

C11. The text includes a neoliberal or a neoconservative economic position (supporting economic growth as the solution, markets self-regulation, minimum government intervention, no taxation of pollution, etc.)

C12. The text includes a mention to human population as a problem.

C13. The text includes a mention of animal-based diets or animal agriculture as a problem.

C14. The text trust technology as a solution to climate change or its consequences.

Examples of C10: Criticizing attitudes (ex: condescending, adamant, patronizing...), practices (ex: indoctrinating in schools and universities), goals (ex: profit-oriented, job- and career-oriented, or climate change defenders), consequences (ex: economic/environment/ethic consequences or climate change policies), ideology (ex: mentioning politics blamed as extremists or fanatics).

D. Focus.

D15. Policies/Solutions.

D16. Scientific approach.

D17. Economic approach.

D18. Ethical approach.

D19. Other.

While counter-frames related to scientific claims (general or specific) are standard in climate change counter-framing theory, it is worth commenting on our third set of counter-frames related to nonscientific claims. Here, we first ( $\mathrm{C} 10)$ attempted to gather data concerning the degree of verbal abuse (for instance of ad hominem attacks), since this can unveil the belligerence of these organizations in Europe. Second (C11), we particularly wanted to examine the extent to which these organizations were linked to the neoliberal or neoconservative economic position, a link which has been identified as very relevant in the US case. Third (C12, C13 \& C14), we wanted to identify the degree of ideological denial of these organizations (Almiron 2020), that is the refusal to accept that some core ideas are systematically kept out of the discussion, including two of the leading causes as identified by Intergovernmental Panel on Climate Change (IPCC) in all their reports (for instance 2014), human overpopulation, and diet (mostly animal-based diet), as long as the technological myth which promotes that all scenarios related to climate change (either global warming is considered anthropogenic or not) rely heavily on technology rather than on modifying human habits. As these human behaviors are not problematized, it follows that their role in climate inaction is denied. Accordingly, by ideological denial, we do not refer to a response skepticism (Capstick and Pidgeon 2014), based on doubts about the efficacy of action taken to address climate change, rather to the anthropocentric denial underlying our failure to respond to climate change. Together, these sets of frames sought to effectively map the contours of think tanks' skeptical stance.

For the coding criteria, we coded presence of a counter-frame in each article (the appear- ance of an argument in one article to the next makes more of an impression than a repeat of that counter-frame within the same text); we collected examples for each criterion for each think tank; in long reports (more than 20 pages), we coded the introduction, the executive summary, and the conclusion sections. Following, particularly, Clifford and Travis (2018), we conducted an iterative approach that is more commonly now deployed and accepted in similar qualitative analysis (e.g., Bazeley and Jackson 2013; Stemler 2001).

\section{Results: climate contrarianism in Europe}

As shown in Fig. 1, the dissemination of climate contrarian discourse available online by the analyzed think tanks in Europe is first dated in the 1990s (the first text found is from 1994), but denial output is not emergent until 2007. A second and very important uptick is then detected from 2015 to 2018. German EIKE, with $73.46 \%$ of all texts gathered, is the main responsible of this second pick, including the 
use of all frames with the exception of the climate policy criticism (B9), which keeps moderately low compared to the other frames in this last stage.

With regard to general scientific claims, our results showed a relevant presence of all three counterframes $(A 1, A 2, A 3)$ in all the observed organizations, with contesting scientific dissemination being the most used. This frame appeared in almost half of all texts analyzed (49.43\%). The second most frequently invoked here were discourses contesting IPCC legitimacy. This counter-frame was found in $29.24 \%$ of texts. Third, discourses contesting scientific consensus and legitimacy (not IPCC) were found in $27.38 \%$ of the sample.

Amongst think tanks, from 1994 to 2018 , the IEM was found to be the CCM organization contesting the most IPCC legitimacy and scientific consensus, with $41.67 \%$ and $66.67 \%$ of texts, respectively, including these counter-frames. Over this period, EIKE was the CCM think tank contesting scientific dissemination the most, with $58.24 \%$ of all its texts including a criticism accordingly. CPS was found to be the CCM organization contesting the least of this set of counter-frames (with 5.56\% of texts contesting IPCC legitimacy and $22.22 \%$ of texts contesting scientific dissemination).

With regard to specific scientific claims, two frames were found in more than two thirds of the texts: the counter-frame acknowledging that climate change is happening, but humans are not the cause (or are not the single cause) (B7) (37.3\%) and the one skeptical with policies (B9) (38.83\%). The frame with the least presence in this set was the one acknowledging that climate change is happening but that we have other major problems to deal with (B8) (9.23\%). The most remarkable finding here, however, was that $22.23 \%$ of texts in these CCM organizations claimed that climate change and global warming is not happening (B4). Also, a $10.90 \%$ of texts analyzed did not only accept that climate change is happening but also argued that it is good, not bad (B6).

As per organizations, EIKE was the think tank with a larger denial of climate change as a whole (B4) with $26.35 \%$ of texts including this counter-frame-while at the other extreme we did not find any text including this argument in the case of AEC and CPS. In this set of frames, up to four organizations produced texts with the counter-frame that acknowledges climate change but denies that we know how serious it is or argues that is not serious (B6) - AEC, GWPF, IEM, and IEA (with 25.71, 24.53, 22.92, and $19.81 \%$, respectively). Also remarkable was the number of texts found in IEM and EIKE ( 43.75 and $42.82 \%$, respectively) that acknowledged global warming but not its anthropogenic causes (B7). And even more high were the percentages of texts with mentions promoting political inaction, that is criticizing climate policies as proven worse than global warming (B9): $77.78 \%$ of LI's texts contain this argument and also $56.25 \%$ of IEM's and $41.50 \%$ of EIKE's texts.

As for the non-scientific claims, $63.93 \%$ of texts included a criticism of non-scientist defenders and policies on a non-scientific basis (C10). All but one think tank (IEM) included this claim in more than $30 \%$ of their texts. This was the case in more than $70 \%$ of texts of $\mathrm{LI}$ and EIKE. Interestingly, mentions to overpopulation (C12) and diet (C13) were almost nonexistent in the whole sample of think tanks (1.92 and $0.84 \%$, respectively) and also the claim of technology (C14) as a solution was very low (less than $7 \%$ of all texts).

The important link with neoliberal and conservative ideology was found in a relevant percentage of the whole sample (C11), 39.25\%. Noteworthy, claims supporting the economic growth as a solution, to market self-regulation, to minimum government intervention, or a critique to taxation of pollution, for instance, were found in all organizations (from $20 \%$ of texts in AEC to $77.78 \%$ of texts in LI).

Finally, the main focus of the text found was the scientific approach, with $43.14 \%$ of texts including this focus as primary stance, while ethics is the least encountered approach (see Fig. 3). Also, the publication of texts gathered in the think tanks' websites, excluding the CPS case (for which posts were undated), showed that the bulk of texts were published recently, from 2014 to 2018 . For instance, for the most radical claim found (B4: climate change is not happening) that the $63.79 \%$ of texts using this counterframe were published between 2015 and 2017. However, the first counter-frame in the sample was found in a 1994 text, while the set of frames here analyzed largely do not emerge until 2004. 


\section{Discussion: Stuck on contrarianism}

Contrarian and CCM labels are imperfect. In developing these labels, there is a danger of excessively focusing on individual or organizational personalities at the expense of political economic, social, and cultural forces. In other words, when focused on the movements of individual contrarians or particular CCM organizations, attention could displace deeper structures and architectures that give rise to the resonance and asymmetrical effectiveness of their claims in the public arena.

The nuances and distinctions between these labels have deservedly been discussed and debated over time. For example, Howarth and Sharman have developed categories and subcategories of skepticism, distinguishing between (motivated) contrarianism, policy- related skepticism, and knowledge-related skepticism (2017: 777-778). They distinguish these labels from the category then of denier, along with sub-categories within (Howarth and Sharman 2017). Furthermore, O'Neill and Boykoff further developed a definition of climate contrarianism by disaggregating claims-making to include ideological motives behind critiques of climate science, and exclude individuals who are thus far unconvinced by the science or individuals who are unconvinced by proposed solutions, as these latter two elements can be more usefully captured through different terminologies (2010). Moving between climate science, politics, and policy, scholars like Dunlap (2013) have pointed out differences between contrarianism derived from ideology and contrarianism derived from scientific evidence. Moreover, McCright (2007) has defined contrarians as those who vocally challenge what they see as a false consensus of mainstream climate science through critical onslaughts on climate science and eminent climate scientists, often with substantial financial support from fossil fuel industry organizations and conservative think tanks.

Amid these nuances, many CCMs have been found to be at the core of the undermining in the US public confidence in climate science and of the reluctance, when not sheer opposition, by policymakers to the necessity of taking steps to reduce carbon emissions (Carmichael and Brulle 2017; Tesler 2018).

From our analysis, we show that US climate change counter-frames have spread across the public sphere by the European organizations as well, particularly in recent years. Moreover, as in the US, climate contrarian think tanks in Europe are also aligned with neoliberal ideologies-neoliberal here understood as a very diverse and wide ideology that still is useful to depict the intellectual network which is currently converging with far-right thought (Plehwe et al. 2020). This resonates with the recent work of a number of authors linking the far-right political parties/followers and climate change denial in Europe. McCright et al. (2016) first confirmed for the region that a majority of European countries (the ones not linked to a Communist past) held the same left-right ideological divide as found in the US, with citizens on the right showing less belief in climate change and less support for action to mitigate it than citizens on the left. Forchtner et al. (2018) found that many tropes in German far-right climate- change communication (from far-right and Nazi magazines and blogs) are familiar from research on conservative climate-change skepticism. Forchtner (2019) latter expanded this view by showing the same convergence between the far-right, neoliberalism and climate change denial in a number of Western, Nordic, and Central European countries. Our research confirms that European contrarian think tanks are aligned with the stances found at the far-right political level in Europe.

It is remarkable also that, although the top CCM think tanks in Europe are medium-sized or even small (in contrast with funding of other European think tanks), and with the exception of EIKE, all have a modest output (in contrast with outputs of other European think tanks, particularly in the UK: Kelstrup 2017), the majority of them remain members of the club of the most influential organizations according to McGann (2019). One exception, EIKE, is precisely the think tank that is by far the brightest star in this constellation, both in terms of focus (degree of belligerence against anthropogenic climate change consensus) and output (number of publications). The absence of this think tank in McGann's list needs further investigation but one reason may simply be language; the fact that EIKE's output is mostly in German, while for instance the other single-focus think tank of the list, GWPF, in spite of having a much smaller contrarian output, uses English, and thus, is more accessible for the international experts contributing to the McGann's ranking. However, because of EIKE's close links to the US climate counter- 
movement, including the Heartland Institute, which is included in the McGann 2018 list, ElKE's absence in the 2018 Global Go To Think Tank Index Report needs further inquiry.

The fact that the main focus of the texts remains on science over this 24-year period-that is, that skeptics in Europe still openly contest science-is also noteworthy, as it is the findings showing that many of the critiques and attacks are not focused on scientists themselves but on other carriers of the information (as journalists, environmental advocates or politicians, for instance). The presence of radically outlying perspectives-as-frames, like B4 (climate change does not happen) and B9 (high degree of verbal belligerence) shows that European CCM organizations cannot be seen as a moderate version of the US one (e.g., Farrell 2016; Oreskes and Conway 2011; Supran and Oreskes 2017). As examples, the lack of problematization of human population and diet and the low appeal to technology as a solution confirm similar counter-framing approaches across continents.

Finally, the proliferation of CCM organizations expressing climate change or global warming counterframes particularly in recent years was surprising. They show that in spite of old and well-worn narratives at use (used by the US CCM since the 1990s, McCright and Dunlap 2000), European CCM efforts remain rather young and still growing.

Three issues may help to explain and illuminate these findings. First, the fact that the majority of contrarian think tanks in our sample (five out of the eight analyzed) were founded between 2003 and 2009 may partly explain such a late emergence of contrarianism in Europe amongst think tanks. Second, the two latest major IPCC reports (AR4 and AR5) may have prompted reactionary CCM activities. Following the publication of the three working group reports and the synthesis reports comprising AR4 by the IPCC in 2007 prompted increased output by the eight European think tanks. Of note, the frame contesting IPCC legitimacy (A1) was also prominent in Europe just after the publication of the 2014 AR5 IPCC reports. Thus, the two increases in output revealed by this research (Fig. 1a) may be a reaction of the think tanks to both reports. This resonates with notions of contrarianism and denial as an antireflexivity force, reacting against "self-confrontation with the unintended and unanticipated consequences of modernity's industrial capitalist order" (McCright and Dunlap 2010: 103).

There is a third reason that may partly explain, at least for some European think tanks, the late emergence of the climate contrarian discourse: it is precisely the previously mentioned alignment with a right-wing populism effervescence in the European Union after the 2008- 2015 great recession (Forchtner 2019)-merging with neoliberalism (Plehwe et al. 2020). EIKE is clear in their mission, stating that their founding in 2007 was a counter-reaction to a "politics of fear" by the German government and media. Likewise, while the $85 \%$ output of the Spanish JDM is published during a period the Socialists were in office-2007-2010-Spanish CCM organization outputs stop abruptly when the right-wing party - much more passive in terms of environmental reaction (Ecologistas en Acción 2018)-won the elections. Finally, in the UK, the Brexit may also be playing a role-since a network of lobbyists, politicians, and campaign groups is accused to be pushing the UK towards a hard-Brexit, "with the aim of axing environmental protection in the name of free-market ideology" (Farand et al. 2019). Thus, at least for these cases, the picks of production may be reflecting an alignment with political contexts.

The question remaining would be, then, why the neoliberals and the far-right are merging with climate change denialism. A few authors have provided some explanations for both the US and Europe. Lockwood (2018) argued that hostility to climate change by right populists and conservatives may be due to the climate agenda being a too complex topic for the simple solutions right populists need to connect with their public. This is also an agenda considered "as being espoused principally by a liberal, cosmopolitan elite, counter to national interests", a view "encompassing the idea that elites are corrupted by special interests, here represented by climate scientists and environmentalists" (Lockwood, p. 11). However, the latest research in Europe is also pointing at an ecomodern denial, so far only studied for countries like Sweden or Norway. This highlights the need for recognizing the role of identities, historical structures, and emotions in climate skepticism, which may reveal that climate change skepticism is intertwined with a masculinity of industrial modernity that is on decline and which defends its values against ecomodern hegemony (Anshelm and Hutman 2014; Krange et al. 2019). 
To summarize, we have found a number of trends and developments that provide insights going forward for further CCM studies. Amongst them, first, we have provided new mapping of the most important contrarian think tanks in Europe and their outputs on climate change. This have produced a list of what probably are the eight most relevant organizations in Western and Central Europe regarding the dissemination of climate change contrarian messages. They are the Austrian Economics Centre (AEC), Centre for Policy Studies (CPS), Europäisches Institut für Klima und Energie (EIKE), Institut Économique Molinari (IEM), Institute of Economic Affairs (IEA), Instituto Juan de Mariana (IJM), Liberales Institut (LI), and The Global Warming Policy Foundation (GWPF).

Second, we conducted systematic framing analysis of the contrarian discourse disseminated by this set of contrarian think tanks in Europe, including the coding of 1669 texts published online from 1994 to 2018. This has unveiled an emergent climate contrarian counter-movement in Europe which shares not only US contrarian discourse and neoliberal stance but also its rhetoric. This revealed a proliferation of denial frames mostly in recent years, particularly from 2015 to 2018, with German Europäisches Institut für Klima und Energie (EIKE) being extremely active during this period, followed by Spanish Instituto Juan de Mariana (IJM) and British Institute of Economic Affairs (IEA), and The Global Warming Policy Foundation (GWPF).

Overall, this study has enlarged considerations of CCM organization counter-frames, discourses, and influences beyond the US and English-only contexts. By mapping and analyzing climate contrarianism emanating from European think tanks over the past two and a half decades (1994-2018), ongoing considerations can more capably grasp international - and at times emergent-expressions and impacts.

Future research can draw on this contribution to further map evident and frequent counter- frames to carbon-based industry interests in Europe and in other countries, languages, and regions around the globe. Future research can also further examine why certain frames (for example, links between dietary choices and climate change (C13)) are largely absent in public discourse in these six countries and potentially in other countries/regions. Further research can also extend into analyses of social media representations about climate change from these eight think tanks.

This research finds that CCM discourses track with many intertwined political economic and cultural identities for a better part of two centuries in the US and EU. Amid differentiated regulatory and societal networks and institutions that have shaped varied carbon-based industry decision-making and practices and divergent institutional arrangements designed address climate change over time (Pulver 2007; Levy and Kolk 2002), in both contexts, CCM discourses tracked similarly. As such, commitments to economic growth and to carbon- based industry, and deeply entrenched technological optimism have been forces influencing discussions of climate change in the public sphere that has been found to give space for similar CCM discourses in both quantity and quality (Farrell 2016; Boykoff and Olson 2013; Carmichael and Brulle 2018). While it is easier to muddy the waters of productive discourse on the causes and consequences of climate change in the twenty-first century-bolstered by elite corporate benefactors (Oreskes and Conway 2011; Supran and Oreskes 2017)-this research has sought to better identify sources and constituents of discursive pollution in the public sphere. 
Almiron N (2020) Rethinking the ethical challenge in climate change lobbying: a discussion of ideological denial. In: Almiron N, Xifra J (eds) Climate change denial and public relations. Strategic communication and interest groups in climate inaction. Routledge, London, pp 9-25

Anshelm J, Hutman M (2014) A green fatwā? Climate change as a threat to the masculinity of industrial modernity. NORMA Int J Masculinity Stud 9(2):84-96

Bazeley P, Jackson K (eds) (2013) Qualitative data analysis with NVivo. Sage Publications Limited, London

Beder S (2001) Neoliberal think tanks and free market environmentalism. Environment Politics 10(2):128-133

Boykoff MT (2011) Who speaks for the climate? Making sense of media reporting on climate change. Cambridge University Press, Cambridge

Boykoff MT (2016) Consensus and contrarianism on climate change. How the USA case informs dynamics elsewhere. Mètode Sci Stud J 6:89-95

Boykoff M, Olson S (2013) 'Wise contrarians' in contemporary climate science-policy-public interactions. Celebrity Stud J 4(3):276-291

Boykoff MT, Rajan SR (2007) Signals and noise: mass-media coverage of climate change in the USA and the UK. Eur Molecul Biol Organizat Rep 8(3):1-5

Brulle RJ (2014) Institutionalizing delay: foundation funding and the creation of U.S. climate change counter-movement organizations. Clim Chang 122:681-694

Brulle RJ (2020) Denialism: organized opposition to climate change action in the United States. In: Konisky D (ed) Handbook of environmental policy. Edward Elgar Publishing, Northampton, pp 328-341

Capstick SB, Pidgeon NF (2014) What is climate change skepticism? Examination of the concept using a mixed methods study of the UK public. Glob Environ Chang 24(1):390-401

Carmichael JT, Brulle RJ (2017) Elite cues, media coverage, and public concern: an integrated path analysis of public opinion on climate change, 2001-2013. Environ Politics 26(2):232-252

Carmichael JT, Brulle RJ (2018) Media use and climate change concern. Int J Media Cult Politics 14(2):243-253

Carter L, Ross A (2018) Revealed: BP and gambling interests fund secretive free market think tank. Unearthed, retrieved from https://unearthed.greenpeace.org/2018/07/30/bp-fundinginstitute-of-economic-affairs-gambling/. Accessed 8 Sept 2020

CEO (2010) Concealing their sources - who funds Europe's climate change deniers? Corporate Europe Observatory, December. Retrieved from https://corporateeurope.org/en/funding-climatechange-denial

Clifford KR, Travis WR (2018) Knowing climate as a social-ecological-atmospheric construct. Glob Environ Chang 49:1-9

Cook J, Oreskes N et al (2016) Consensus on consensus: a synthesis of consensus estimates on humancaused global warming. Environ Res Lett 11:048002

Cook J, Ellerton P, Kinkead D (2018) Deconstructing climate misinformation to identify reasoning errors. Environ Res Lett 13(2):024018

Deleja-Hotko V, Müller A-K, Traufetter G (2019) AfD hopes to win votes by opposing climate protection. Spiegel, retrieved from https://www.spiegel.de/international/germany/afd-seeks-votes-byopposing-climate- protection-a-1265494.html. Accessed 8 Sept 2020

Derrida J (1978) Structure, sign, and play in the discourse of the human sciences. In: Derrida J (ed) Writing and difference. University of Chicago Press, Chicago, pp 278-293

Dunlap RE (2013) Climate change skepticism and denial: an introduction. Am Behav Sci 57(6):691-698 
Dunlap RE, Jacques PJ (2013) Climate change denial books and conservative think tanks: exploring the connection. Am Behav Sci 57(6):699-731

Ecologistas en Acción (2018) Balance ambiental negativo de los seis años de Gobierno del Partido Popular [Negative environmental outcome of the six years of Partido Popular's administration]. https://www. ecologistasenaccion.org/36084/balance-ambiental-negativo-de-los-seis-anos-degobierno-del-partido- popular/ Accessed 7 July 2020

Farand C, Hope M, Collet-White R (2019) Mapped: a who's who of Brexit and climate science denial.

Desmog, retrieved from https://www.desmog.co.uk/2019/06/07/brexit-climate-denier-map\#TuftonSt. Accessed 8 Sept 2020

Farrell J (2016) Network structure and influence of climate change countermovement. Nat Clim Chang 6(4):370-374

Forchtner B (ed) (2019) The far right and the environment. Politics, discourse and communication. Routledge, London

Forchtner B, Kroneder A, Wetzel D (2018) Being skeptical? Exploring far-right climate change communication in Germany. Environ Commun 12(5):589-604

Goffman E (1974) Frame analysis: an essay on the organization of experience. Harper \& Row, New York

Hornsey MJ, Harris EA, Fielding KS (2018) Relationships among conspiratorial beliefs, conservatism and climate scepticism across nations. Nature Clim Change 8:614-620. https://doi.org/10.1038/s41558-018- 0157-2

Howarth C, Sharman A (2017) Influence of labeling and incivility on climate change communication. Oxford Res Encyclopedia Clim Sci 2:772-784

IPCC (2014) Climate change 2014: synthesis report. In: Core Writing Team, Pachauri RK, Meyer LA (eds) Contribution of working groups I, II and III to the fifth assessment report of the intergovernmental panel on climate change. IPCC, Geneva

Jacques PJ, Dunlap RE, Freeman M (2008) The organization of denial: conservative think tanks and environ- mental scepticism. Environ Politics 17:349-385

Kelstrup JD (2017) Quantitative differences in think tank dissemination activities in Germany, Denmark and the UK. Policy Sci 50:125-137

Krange O, Kaltenborn BP, Hultman M (2019) Cool dudes in Norway: climate change denial among conservative Norwegian men. Environ Sociol 5(1):1-11

Levy DL, Kolk A (2002) Strategic responses to global climate change: conflicting pressures on multinationals in the oil industry. Business Politics 4(3):275-300

Liberales Institute (2020) The Institute. Liberales Institute Website. https://www.libinst.ch/?i=home\%2D \%2Den. Accessed 1 July 2020

Lockwood M (2018) Right-wing populism and the climate change agenga: exploring the linkages. Environ Politics 27(4):712-732

Mandel K (2016) UK climate denial think tank global warming policy foundation sets up US fundraising arm. Desmog, retrieved from https://www.desmog.co.uk/2016/05/06/uk-climate-denial-thinktank-gwpf-global- warming-policy-foundation-sets-us-fundraising-arm. Accessed 8 Sept 2020

Mayer J (2017) Dark money: the hidden history of the billionaires behind the rise of the radical right. Anchor Books, New York

McCright AM (2007) Climate contrarians. In: Moser SC, Dilling DL (eds) Creating a climate for change: communicating climate change and facilitating social change. Cambridge University Press, Cambridge, pp 200-212

McCright AM, Dunlap RE (2000) Challenging global warming as a social problem: an analysis of the conservative movement's counter-claims. Soc Probl 47:499-522 
McCright AM, Dunlap RE (2003) Defeating Kyoto: the conservative movement's impact on U.S. climate change policy. Soc Probl 50:348-373

McCright AM, Dunlap RE (2010) Anti-reflexivity: the American conservative movement's success in undermining climate science and policy. Theory Cult Soc 26:100-133

McCright AM, Charters M, Dentzman K, Dietz T (2015) Examining the effectiveness of climate change frames in the face of a climate change denial counter-frame. Top Cogn Sci 8:76-97

McCright AM, Dunlap RE, Marquart-Pyatt ST (2016) Political ideology and views about climate change in the European Union. Environ Politics 25(2):338-358

McGann JG (2019) 2018 Global Go to Think Thank Index \& Abridged Report. University of Pennsylvania, Philadelphia

Medvetz T (2012) Think tanks in America. The University of Chicago Press, Chicago

Monbiot G (2018) Dark money lurks at the heart of our political crisis. The Guardian, retrieved from https://www.theguardian.com/commentisfree/2018645/jul/18/dark-money-democracypolitical-crisis- institute-economic-affairs. Accessed 8 Sept 2020

Nelson TE, Oxley RA, Clawson ZM (1997) Media framing of a civil liberties conflict and its effect on tolerance. Am Polit Sci Rev 91(3):567-583

Norgaard KM (2011) Climate denial: emotion, psychology, culture, and political economy. In: Dryzek JS,

Norgaard RB, Schlosberg D (eds) The Oxford Handbook of Climate Change and Society. Oxford University

Press, Oxford, pp 399-413

O’Neill SJ, Boykoff MT (2010) Climate denier, skeptic, or contrarian? Proc Natl Acad Sci. https://doi. org/ 10.1073/pnas.1010507107

Oreskes N, Conway EM (2011) Merchants of doubt: how a handful of scientists obscured the truth on issues from tobacco smoke to global warming. Bloomsbury Publishing, New York

Parienté J, Laurent S (2014) Le « jour de libération fiscale » est-il un indicateur sérieux? Le Monde, retrieved from https://www.lemonde.fr/les-decodeurs/article/2014/07/28/le-jour-deliberation-fiscale-est-il-un- indicateur-serieux_4463709_4355770.html. Accessed 8 Sept 2020

Plehwe D (2011) Transnational discourse coalitions and monetary policy: Argentina and the limited powers of the "Washington Consensus.". Criti Policy Stud 5:127-148

Plehwe D (2014) Think tank networks and the knowledge-interest nexus: the case of climate change. Criti Policy Stud 8(1):101-115

Plehwe D (2017) Social Networks of Influence in Europe - and Beyond. In: Büllesbach D, Cillero M, Stolz L (eds) Shifting baselines of Europe. New perspectives beyond neoliberalism and nationalism transcript, pp 147-157

Plehwe D, Slobodian Q, Mirowski P (eds) (2020) Nine lives of neoliberalism. Verso, London. https://www. econstor.eu/handle/10419/215796

Pulver S (2007) Making sense of corporate environmentalism: an environmental contestation approach to analyzing the causes and consequences of the climate change policy split in the oil industry. Organ Environ 20(1):44-83

Raico R (2011) Neither the wars nor the leaders were great. Misses.org, retrieved from https://mises. org/library/neither-wars-nor-leaders-were-great. Accessed 8 Sept 2020

Rothbard M N (2010) The learned extremist: Juan de Mariana. Mises Institute. https://mises.org/library/ learned- extremist-juan-de-mariana. Accessed 1 July 2020

Rowell A (2007) Exxon's foot soldiers: the case of the international policy network. In: Dinan W, Miller D (eds) Thinker, faker, spinner, spy: corporate PR and the assault on democracy. Pluto Press, London, pp 94-116 
Stemler S (2001) An overview of content analysis. Pract Assess Res Eval 7(17):137-146

Supran G, Oreskes N (2017) Assessing ExxonMobil's climate change communications (1977-

2014). Environ Res Lett 12(8):084019

Tesler M (2018) Elite domination of public doubts about climate change (not evolution). Political Communication 35(2):306-326

Union of Concerned Scientists (2007) Smoke, mirrors \& hot air: how ExxonMobil uses big tobaccos tactics to manufacture uncertainty on climate science. Union of Concerned Scientists, Cambridge

\section{FIGURES}

Fig.1 Output and counter-frames over time. a. Number of publications per think tank over time. b. Percentage of use of scientific and non-scientific counter-frames over time

a

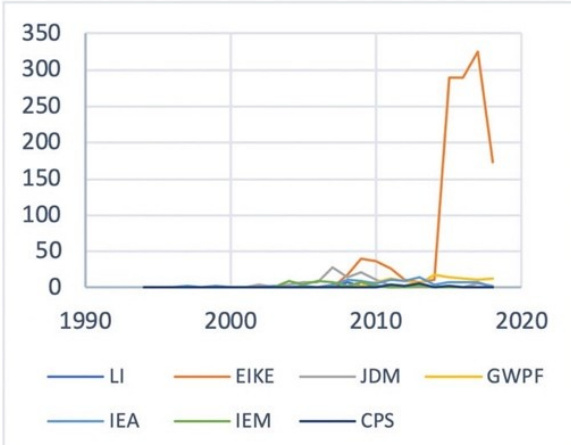

b

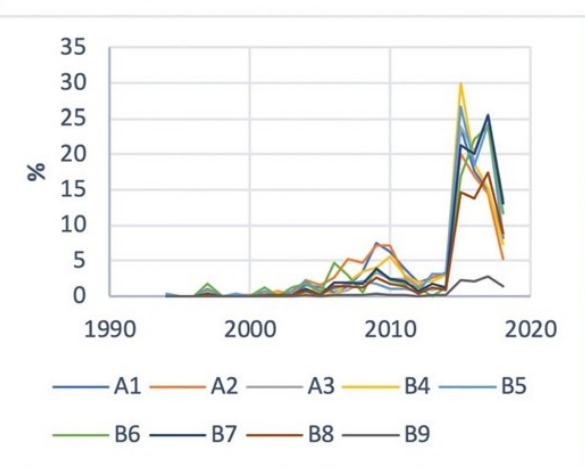

Fig.2 Counter-frames appearance (\% of articles per think tank). a .General scientific counter-frames. b. Specific scientific counter-frames. c. Criticism of advocates on a non-scientific basis. d. Ideological denial

a

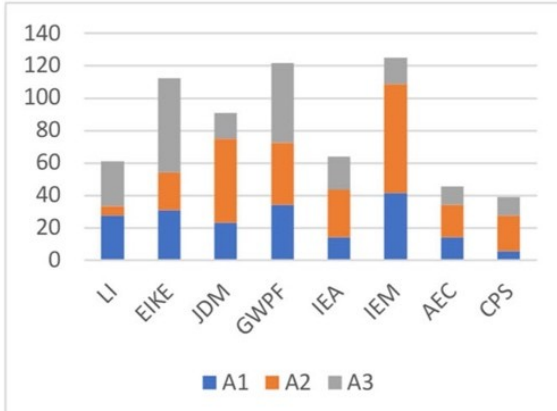

c

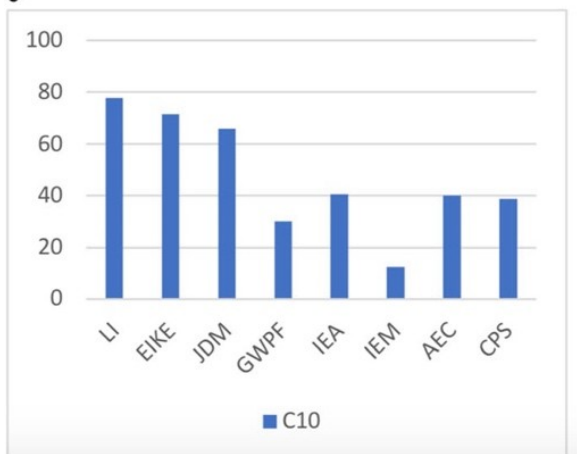

b

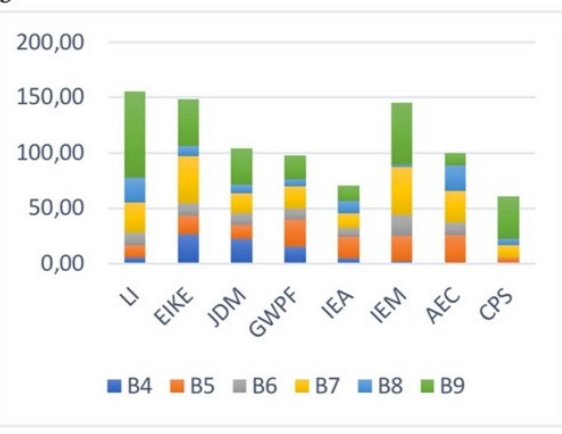

d

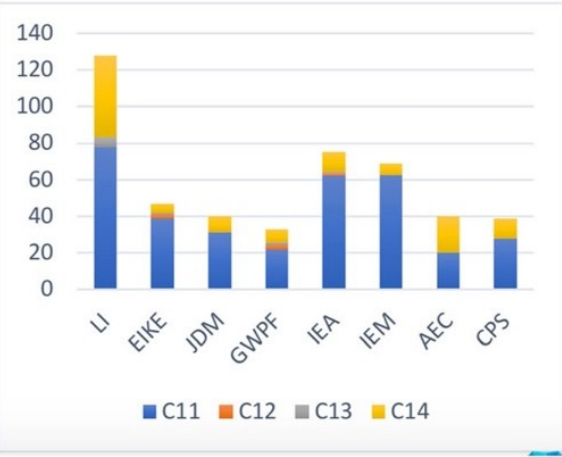


Fig.3 Focus (\% of articles per think tank)

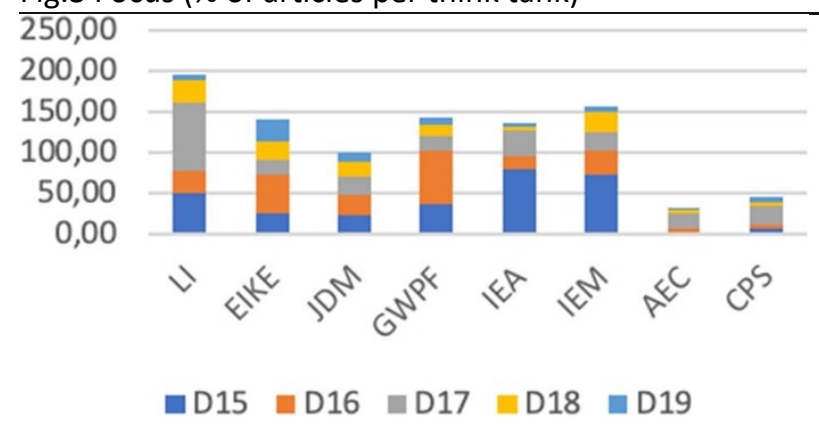

Table 1: European CCM think tanks analyzed

\begin{tabular}{|c|c|c|c|c|c|c|}
\hline Think tank & $\begin{array}{c}\text { Texts including } \\
\text { climate change or } \\
\text { global warming topics } \\
N=1,669\end{array}$ & $\begin{array}{l}\% \text { of } \\
\text { total } \\
\text { texts }\end{array}$ & Country & $\begin{array}{l}\text { Language } \\
\text { coded }\end{array}$ & $\begin{array}{l}\text { Year of } \\
\text { foundin } \\
\quad \mathrm{g}\end{array}$ & $\begin{array}{l}\text { Time range } \\
\text { of posts }\end{array}$ \\
\hline AEC & 35 & 2.85 & Austria & English & 2007 & Undated \\
\hline CPS & 18 & 1.08 & United Kingdom & English & 1974 & 2007-2016 \\
\hline EIKE & 1,226 & 73.46 & Germany & German & 2007 & $2008-2018$ \\
\hline GWPF & 106 & 6.35 & United Kingdom & English & 2009 & 2009-2018 \\
\hline IEA & 106 & 6.35 & United Kingdom & English & 1955 & 1994-2017 \\
\hline IEM & 48 & 2.88 & France & French & 2003 & 2004-2013 \\
\hline JDM & 112 & 6.71 & Spain & Spanish & 2005 & 2001-2018 \\
\hline LI & 18 & 1.08 & Switzerland & German & 1979 & 2007-2017 \\
\hline \multicolumn{7}{|c|}{$\begin{array}{l}\text { Sources: } \\
\text { AEC (Austrian Economics Centre): https://www.austriancenter.com/ } \\
\text { CPS (Centre for Policy Studies): https://www.cps.org.uk/ } \\
\text { EIKE (Europäisches Institut für Klima und Energie (EIKE): https://www.eike-klima-energie.eu/ } \\
\text { GWPF (The Global Warming Policy Foundation): https://www.thegwpf.org/ } \\
\text { IEA (Institute of Economic Affairs): https://iea.org.uk/ } \\
\text { IEM (Institut Économique Molinari): http://www.institutmolinari.org/ } \\
\text { JDM (Instituto Juan de Mariana): https://www.juandemariana.org } \\
\text { LI (Liberales Institut): https://www.libinst.ch }\end{array}$} \\
\hline
\end{tabular}

